2. To: (Receiving organization)

Distribution

5. Proj./Prog./Dept./Div.: 8AT00

8. Originator Remarks:

For Review and Release

3. From: (originating organization) Engineering Testing Laboratory - 8A100

6. Design Authority/ Design Agent/Cog. Engr.:

K. S. Witwer
4. Related EDT No.:

$N / A$

7. Purchase Order No.:

$N / A$

9. Equip./Component No.:

$N / A$

10. System/Bldg./Facility:

11. Receiver Remarks: 11A. Design Baseline Document? [] Yes [X] No

\section{Genera]}

12. Major Assm. Dwg. No.: $N / A$

13. Permit/Permit Application No.: N/A

14. Required Response Date: ASAP

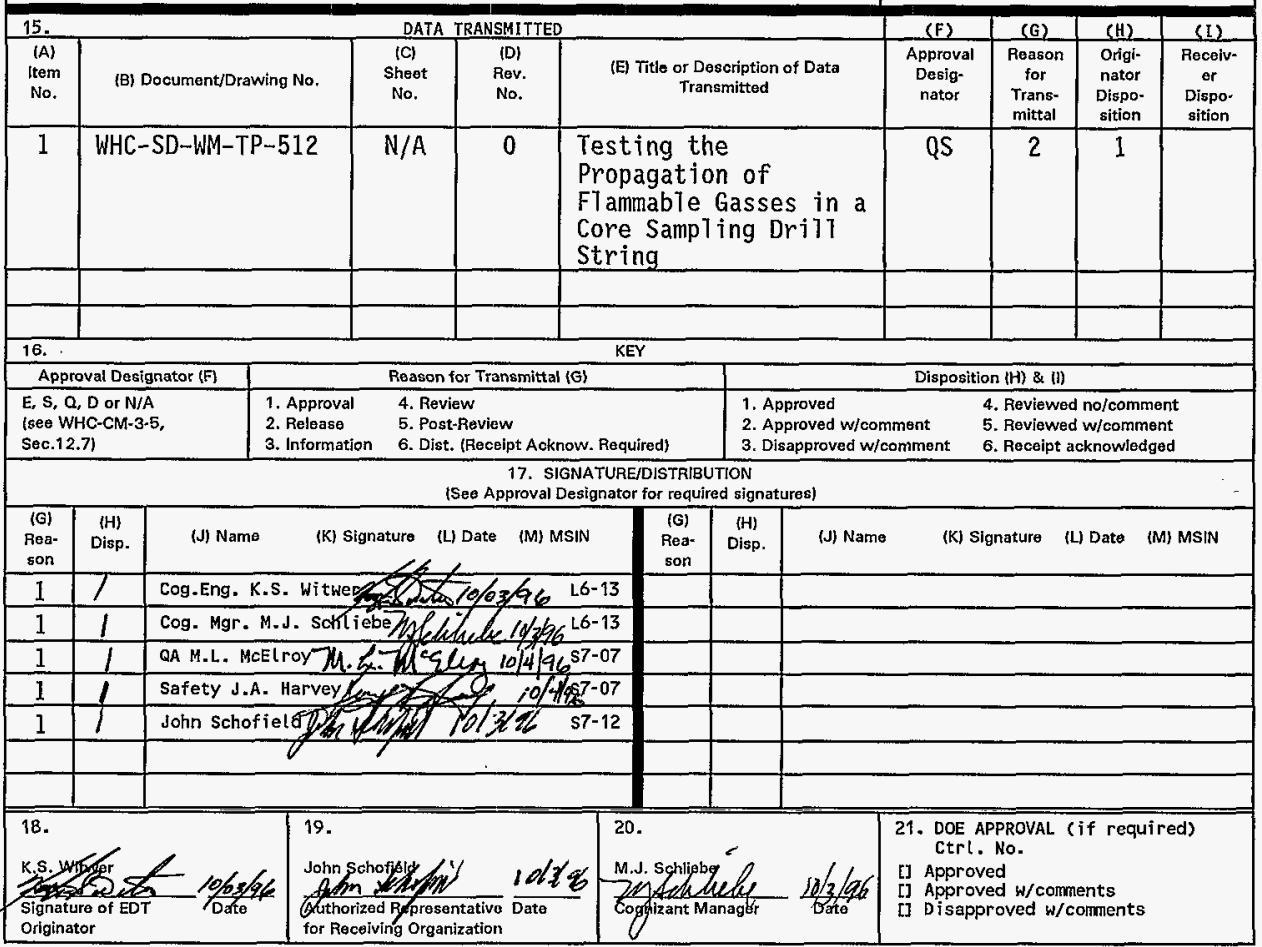

BD-7400-172-2 (05/96) GEF097 


\section{Testing the Propagation of Flammable Gasses in a Core Sampling Drill String}

\section{Keith S. Witwer}

Westinghouse Hanford Co., Richland, WA 99352

U.S. Department of Energy Contract DE-AC06-87RL10930

\begin{tabular}{|c|c|c|}
\hline $\begin{array}{l}\text { DT/ECN: } 6 \\
\text { Prg Code: } \\
\text { 3\&R Code: }\end{array}$ & $\begin{array}{l}601039 \\
8 A 100 \\
\text { EW3120074 }\end{array}$ & $\begin{array}{l}\text { UC: } 2070 \\
\text { Charge Code: } \\
\text { Total Pages: }\end{array}$ \\
\hline
\end{tabular}

Key Words: Ignitability, Drill String, Bureau of Mines, Core Sampling

Abstract: This document describes testing to be carried out at the Pittsburgh Research Center to determine the effects of an expTosion occuring within a length of drill pipe. The results will help quantify hazards involved with core sampling in a Flammable Watch List Tank on the Hanford Nuclear Site.

TRADEMARK DISCLAIMER. Reference herein to any specific commercial product, process, or service by trade name, trademark, manufacturer, or otherwise, does not necessarily constitute or imply its endorsement, recommendation, or favoring by the United States Government or any agency thereof or

its contractors or subcontractors.

Printed in the United States of America. To obtain copies of this document, contact: WHC/BCS Document Control Services, P.O. Box 1970, Mailstop H6-08, Richland WA 99352, Phone (509) 372-2420, Fax (509) 376-4989.
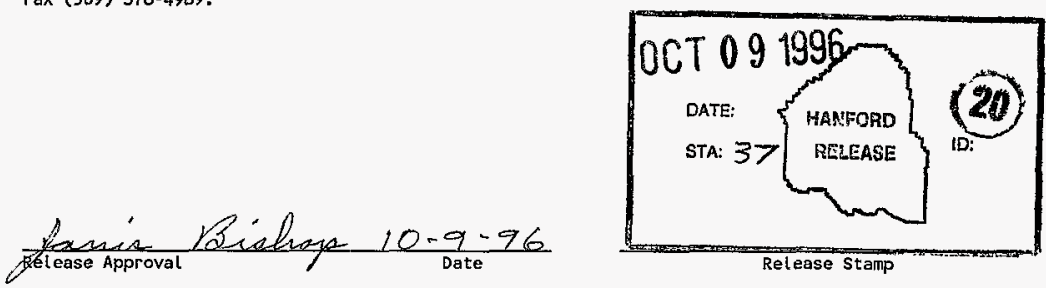


\title{
TESTING THE \\ PROPAGATION OF FLAMMABLE GASSES IN A CORE SAMPLING DRILL STRING
}

\author{
WHC-SD-WM-TP-512 \\ REV. 0
}

SEPTEMBER 25, 1996

Keith S. Witwer

Engineering Testing Laboratory Westinghouse Hanford Company

Richland, Washington 
TABLE OF CONTENTS

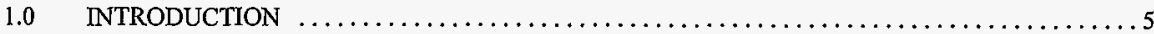

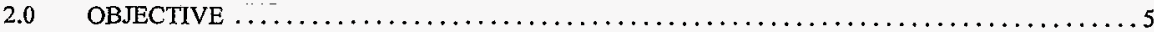

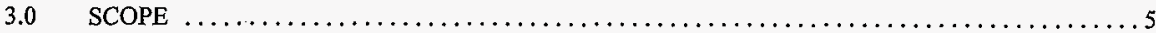

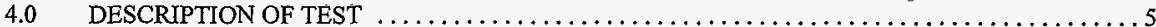

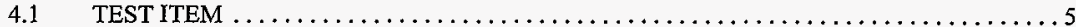

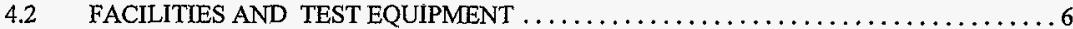

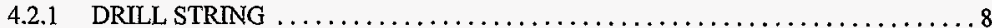

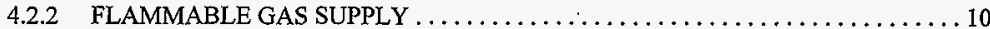

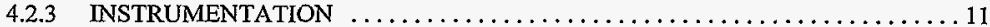

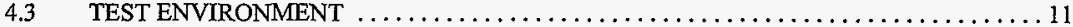

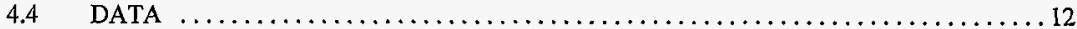

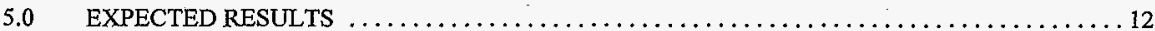

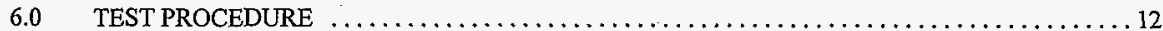

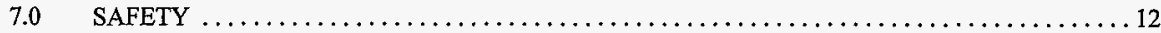

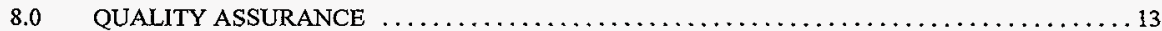

9.0 ORGANIZATIONAL RESPONSIBILITIES $\ldots \ldots \ldots \ldots \ldots \ldots \ldots \ldots \ldots \ldots \ldots \ldots \ldots \ldots$

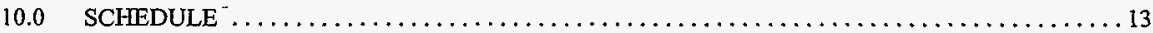

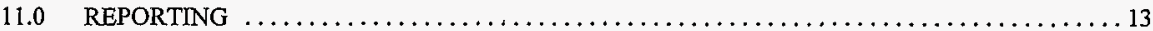

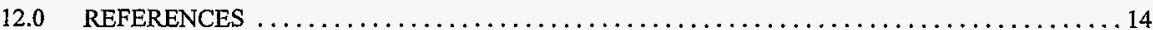




\section{LIST OF FIGURES}

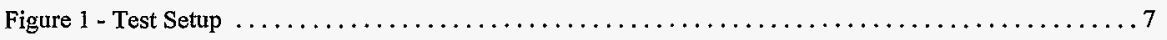

\section{LIST OF PHOTOGRAPHS}

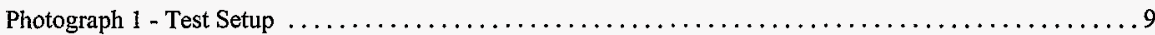

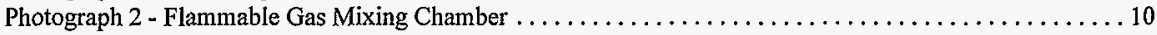

\section{LIST OF TABLES}

Table 1: Pertinent Equipment Items .11 
WHC-SD-WM-TP-512

REV. 0

PAGE 5 OF 14

\section{TESTING THE \\ PROPAGATION OF FLAMMABLE GASSES \\ IN A CORE SAMPLING DRILL STRING}

\section{0}

INTRODUCTION

The recently completed Safety Assessment for Core Sampling in Flammable Gas Watch List Tanks ${ }^{1}$ (Safety Assessment) discussed the possibility of an ignition of flammable gasses while sampling. Specifically, an ignition occurring in the vertically suspended drill string is a concern because of the possibility of the flame propagating out of the drill string and into the waste media. This document describes testing that will show the results of an ignition induced inside a length of drill string.

\subsection{OBJECTIVE}

The objective of this scouting or "scoping" testing is to determine, under different configurations, if an ignition of flammable gasses within a length of drill string will spread through a column of water (simulating liquid waste) and out the end of a length of drill string. It is believed that very little trapped gas exists within the first three feet of waste in a flammable gas watch list tank. Thus if an ignition were to occur within the drill string and spread into the waste while the end of the drill string was within this first three feet, the risk of contacting flammable gas (and any subsequent flame propagation) is low. If no gas is expelled during testing with the drill string placed in one to three feet of water, then a spread of an ignition will not occur and the issue of the propagation of flammable gas at this depth or any deeper depth (where the hydrostatic head is even greater) is eliminated.

Variables such as the height of the column of water at the bottom end of the drill string, the length of the drill string (and subsequent total amount of flammable gas), the open or closed position of a venting valve, and the location of the spark which ignites the gas will be varied to try to find a condition where gas will not escape through the water layer.

\subsection{SCOPE}

This testing is directed by the Westinghouse Characterization Field Engineering Group and will be done by the Engineering Testing Laboratory (ETL) and the United States Bureau of Mines (USBM) personnel at the Pittsburgh Research Center in Pennsylvania. A Statement of Work (SOW) which describes the test specifications and accuracy, deliverables, schedule, cost, responsibilities, etc. and an extension to the current Memorandum of Agreement 14-09-005-3666 between WHC and the USBM supports this testing.

USBM will provide consultation, design information, test support, and test results. ETL will document the results from this testing in a supporting ducument test report to the Characterization Design Group.

\subsection{DESCRIPTION OF TEST}

\subsection{TEST ITEM}

Testing will start with the following baseline "worst-case" scenario. A stoichiometric hydrogen and air mixture will be ignited near the top of a $16.8 \mathrm{~m}$ (55-ft) length of air- tight drill string. The bottom of the open drill string will be immersed in $30.5 \mathrm{~cm}$ ( 12 inches) of water. If the ignition of the gasses causes enough 
WHC-SD-WM-TP-512

REV. 0

PAGE 7 OF 14

Figure 1 - Test Setup

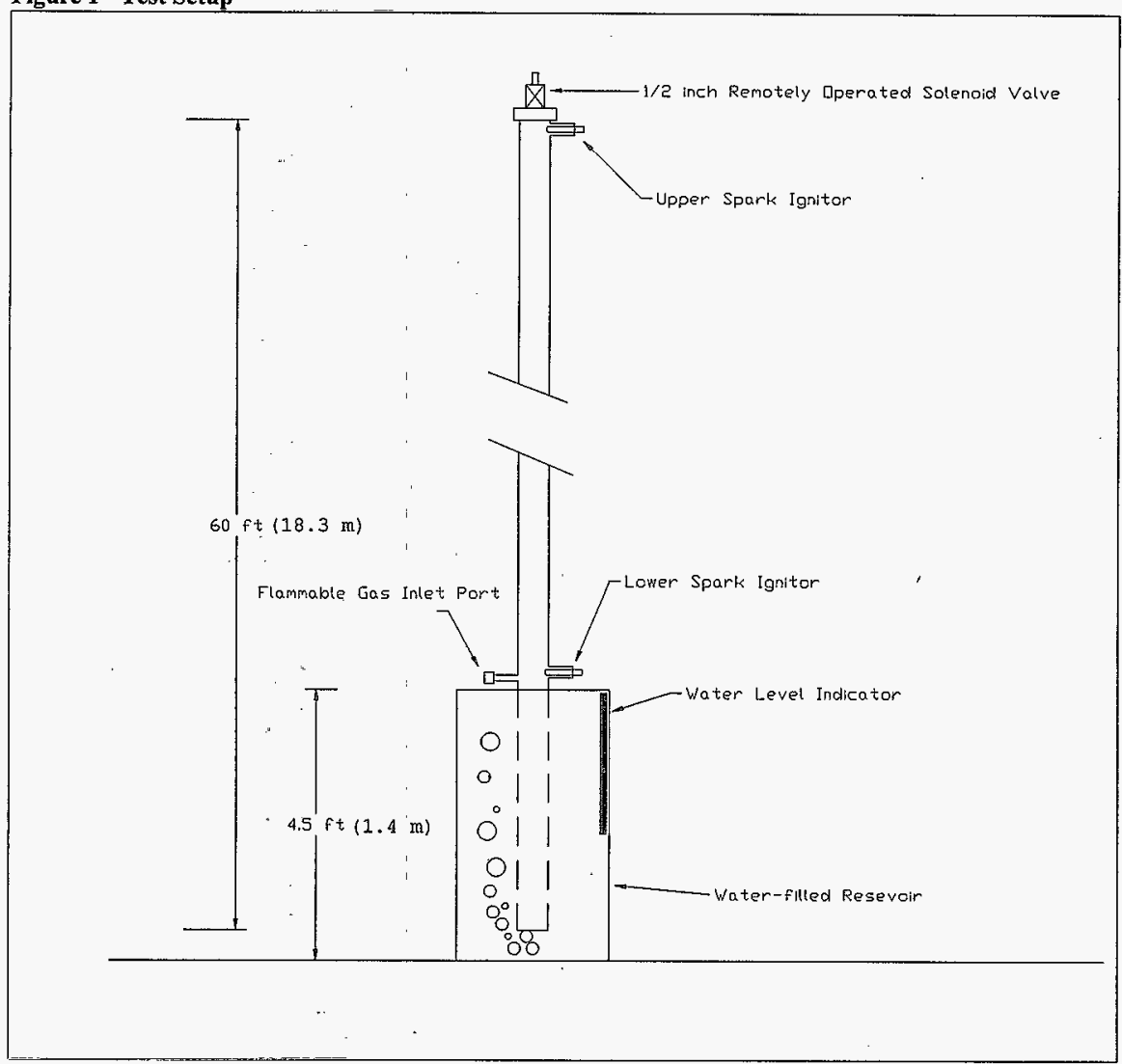


WHC-SD-WM-TP-512

REV. 0

PAGE 8 OF 14

\subsubsection{DRILL STRING}

A thirty to sixty-foot length of standard 2.25 inch (OD) steel drill string will be supported vertically with a crane or other holding device such that the lower 31 to $93 \mathrm{~cm}$ of the drill string is positioned within a container of water. This container of water will provide an indication of either:

1. That enough energy is developed during an ignition to force the pressurized gas/flame front out the end of the drill string - observed as gas escaping out the bottom of the drill string (using a high speed video camara), or

2. Insufficient energy is developed during an ignition to expel gasses and instead only a rise in water level is observed.

The proposed method of supporting the drill string is shown in Photograph 1 below. 
WHC-SD-WM-TP-512

REV. 0

PAGE 9 OF 14

Photograph 1 - Test Setup

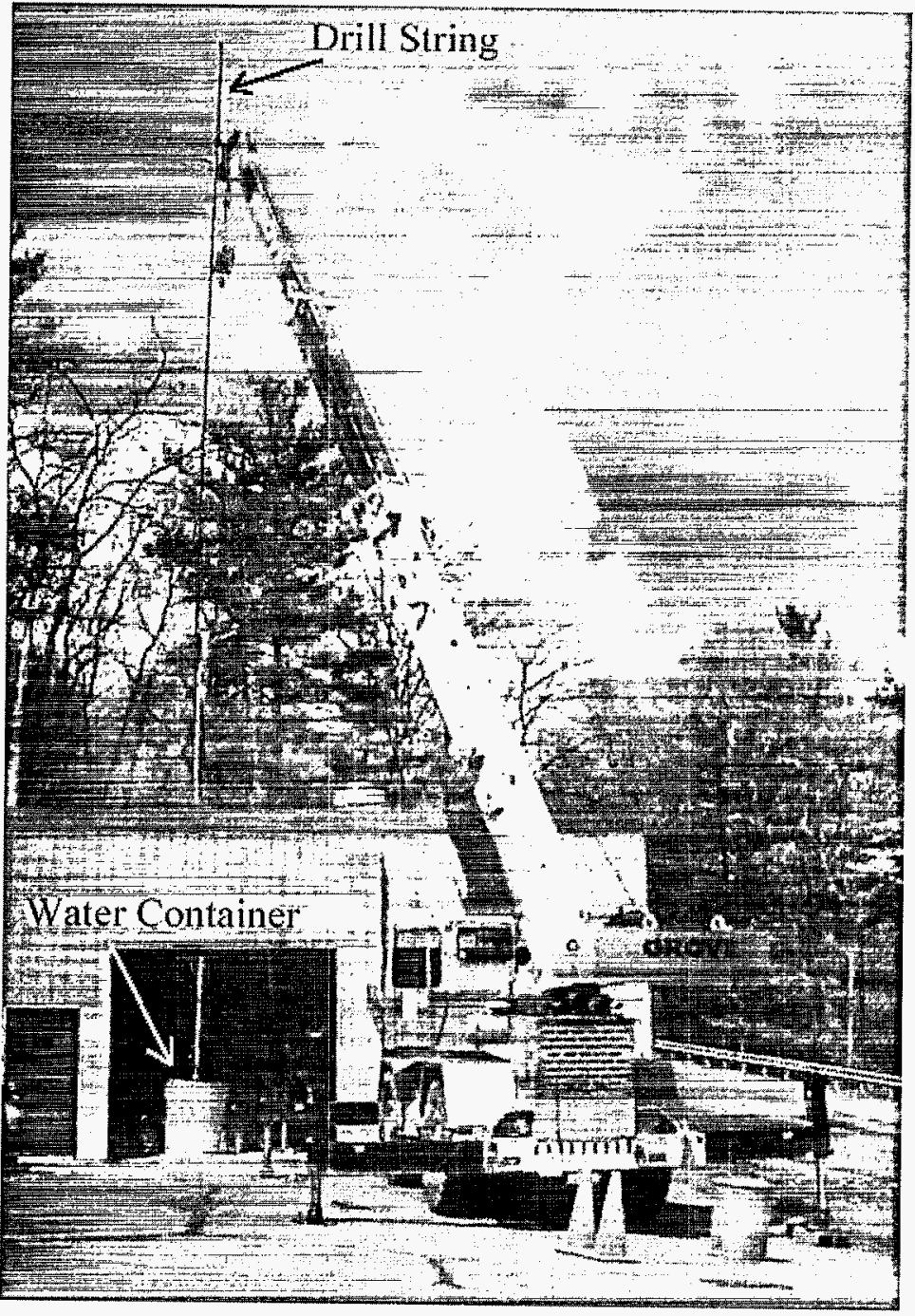


The container of water simulates the liquid waste that will be present in the drill string during actual field sampling. The container should be of a diameter that is both small enough to easily see a change in water level and yet big enough to allow adequate viewing of the end of the drill string with a video camara during the test.

\subsubsection{FLAMMABLE GAS SUPPLY}

Previous ignitability testing ${ }^{2}$ showed that a stoichiometric gas mixture of hydrogen and air would be bounding for ignitability tests and this mixture will also be used in this testing.

The pressurized mixing chamber, shown in Photograph 2 below, is used to provide the flammable gas to the drill string. A vacuum is initially pulled on the mixing chamber and then the individual gas species are supplied at the required partial pressures to create the stoichiometric hydrogen/air mixture. The gas mixture will be released from the pressurized mixing chamber into the drill string for eight minutes at $28 \mathrm{liter} / \mathrm{minute}$ to both purge the drill string of any atmospheric gasses and to fill it with the flammable gas completely. This eight minute purge time was shown in previous testing to be more than sufficient to purge a $18.3 \mathrm{~m}$ (60-ft) length of drill string of atmospheric gasses completely. If a non-sealed drill string is used, the flammable gas will continue to flow after the initial eight minute purge at a reduced rate of $5.7 \mathrm{liter} / \mathrm{min}$. The gas line will be heated to provide an approximate $100^{\circ} \mathrm{C}$ gas entering the drill string. The mixing chamber is shown in photograph 2 below.

Photograph 2 - Flammable Gas Mixing Chamber

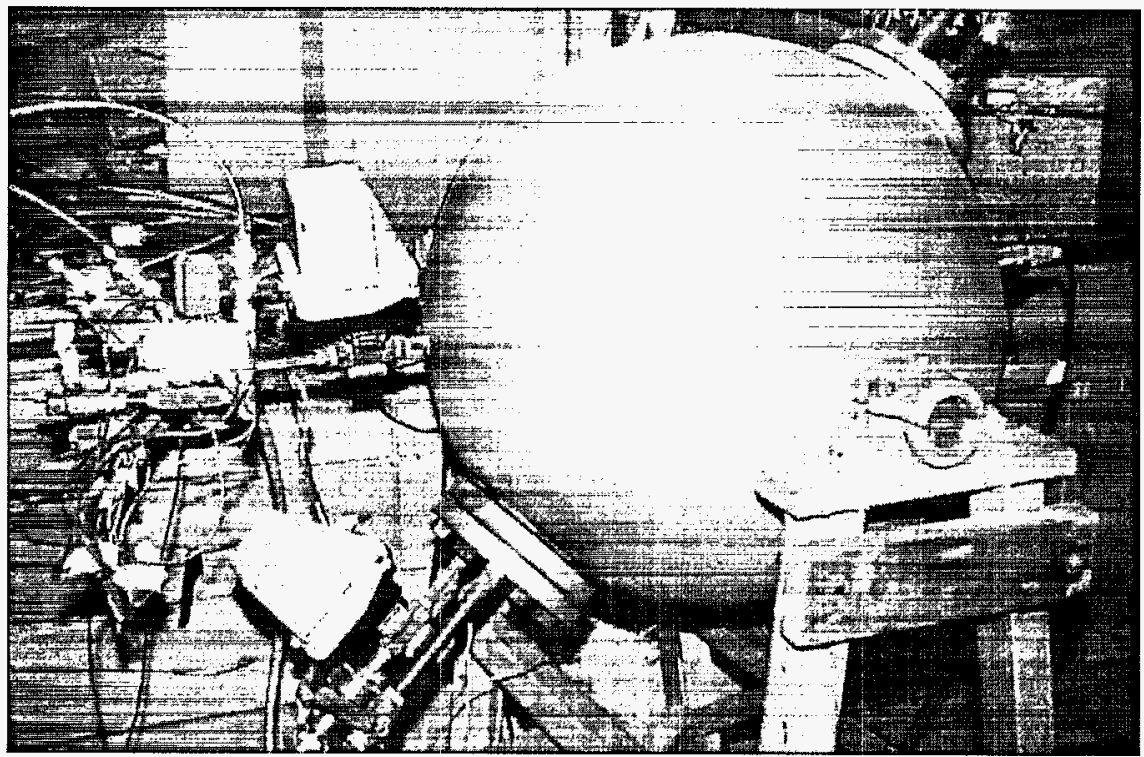




\subsubsection{INSTRUMENTATION}

A pressure transducer will be mounted on the drill string to indicate the timing and magnitude of an ignition. In addition, a liquid level device will be mounted on the water container to indicate the water level rise after ignition. Both these transducers will feed information to a remote data acquisition system for recording. A high speed video camera will also be set up next to the water container to view the bottom of the drill string. The camera will provide a remote indication and record of any gas release from the drill string. A spark inducing device, such as an electric match, will be installed to provide the intentional ignition of the flammable gas. Information from the sensors will be fed to a remote data acquisition system for recording. operation.

Table 1, below, shows the measuring equipment with their corresponding sensitivity and range of

Table 1: Pertinent Equipment Items

\begin{tabular}{||c|c|c|}
\hline Equipment Item & Accuracy/Sensitivity & Type/Range \\
\hline $\begin{array}{c}\mathbf{H}_{2} \text { Partial Pressure Transducer } \\
\text { (mounted on inlet line to mixing } \\
\text { chamber) }\end{array}$ & $\begin{array}{c}+/-0.1 \text { psi or }+/-0.5 \% \\
\text { (whichever is larger) }\end{array}$ & $\begin{array}{c}\text { Strain Gage } \\
0-50 \text { psia }\end{array}$ \\
\hline $\begin{array}{c}\mathbf{O}_{2} \text { Partial Pressure Transducer } \\
\text { (mounted on inlet line to mixing } \\
\text { chamber) }\end{array}$ & $\begin{array}{c}+/-0.1 \text { psi or }+/-0.5 \% \\
\text { (whichever is larger) }\end{array}$ & $\begin{array}{c}\text { Strain Gage } \\
0-50 \text { psia }\end{array}$ \\
\hline $\begin{array}{c}\text { Explosion Pressure Transducer } \\
\text { (mounted on drill string) }\end{array}$ & $\begin{array}{c}+/-0.2 \text { psi or }+/-1 \% \\
\text { (whichever is larger) }\end{array}$ & $\begin{array}{c}\text { Strain Gage } \\
0-100 \text { psia or 0-200 psia }\end{array}$ \\
\hline Liquid Level Transducer & TBD & TBD \\
\hline High Speed Camera & 200 frames/sec & High Speed V.H.S. \\
\hline Gas Temperature Probe & $+/-2.2^{\circ} \mathrm{C}$ & Type K Thermocouple \\
\hline
\end{tabular}

\subsection{TEST ENVIRONMENT}

Testing will be conducted at the Pittsburgh Research Center in Pittsburgh, PA. The USBM Fires, Explosives and Explosions Group will be responsible for the actual testing site and necessary support equipment. The Pittsburgh facility is ideally suited for these tests since it is designed to handle the potential explosion hazard. Testing will occur in an area that is physically separated, by a safety barrier, from test personnel. USBM standard operating procedures and safety oversight will be in effect for these tests. 


\subsection{DATA}

Data will be collected both electronically using a PC, and in a WHC controlled laboratory log book ${ }^{3}$. Parameters of interest include the pressure and time of an ignition, maximum water level during and/or after ignition, presence of escaped gas into the water reservoir, partial pressures of the hydrogen and air flowing into the mixing chamber, flow rate of the flammable gas from the mixing chamber to the drill string and temperature of the gas flowing into the drill string.

\subsection{EXPECTED RESULTS}

The testing will show if an explosion is of sufficient energy to force combustion gasses out the end of a length of partially submerged drill string. Data is not available to predict the outcome of the tests sufficiently.

\subsection{TEST PROCEDURE}

Below is the step-by-step procedure to be used for the tests.

1) Position the required length of drill string and attached measuring equipment into the container ofwater. Adjust water level to the required depth.

2) Insure that all pertinent measuring equipment is operating correctly.

3) Remove personnel from vicinity of drill string and begin purging drill string with flammable gas.

4) Continue filling at $28 \mathrm{liter} / \mathrm{min}$ for eight minutes. After eight minutes, reduce the flow rate of used).

flammable gas to approximately six liter/min for duration of the test (if a non-sealed drill string isbeing

5) Begin recording with data acquisition system and video camera.

๑) Ignite gas within drill string using a remotely controlled electric match.

7) Review test and set up for a new test based on the results.

\subsection{SAFETY}

An explosion (detonation or deflagration) hazard exists. The USBM has facilities, personnel, and safety procedures prepared to accommodate an explosion, should one occur. 


\subsection{QUALITY ASSURĀNCE}

The pertinent measuring devices will be calibrated or characterized by the USBM before use. Information concerning each test will be recorded in an official WHC log book by the Test Director - Keith Witwer (or alternate).

\subsection{ORGANIZATIONAL RESPONSIBILITIES}

\section{Engineering Testing Laboratory - WHC}

Responsible for test direction and for provision and transportation of major components needed for testing to the USBM Pittsburgh Research Center and back to Hanford at conclusion of testing. WHC is also responsible for the final test report writing and release. WHC Cognizant Engineer is Keith Witwer. Other WHC points of contact are John Schofield of WHC Characterization Field Engineering, and Michael Schliebe of the WHC Engineering Testing Laboratory.

\section{Pittsburgh Research Center, USBM-Pittsburgh}

Responsible for providing the testing facility, the setup of testing, various flammable gas hardware and instrumentation, support personnel, and assistance in preparing a final test report. This testing falls under a Memorandum of Agreement ${ }^{4}$ between WHC and USBM. USBM points of contact are Kenneth L. Cashdollar and Aldo Furno of the Fires, Explosives and Explosions Group.

\subsection{SCHEDULE}

WHC personnel will travel to Pittsburgh approximately one week after shipment of necessary drill equipment. The setup of the equipment will commence as soon as possible and actual testing will begin shortly after that. Testing is estimated to take between one and two weeks and is expected to start the first part of October 1996.

\subsection{REPORTING}

A Supporting Document Test Report will be generated and delivered to Characterization Field Engineering within four weeks after completion of testing. 
WHC-SD-WM-TP-512

REV. 0

PAGE 14 OF 14

\subsection{REFERENCES}

1. Unal, C. et al. "A Safety Assessment for Push-Mode and Rotary-Mode Core Sampling in Flammable Gas single Shell Tanks: Hanford Site, Richland, Washington, WHC-SD-WM-SAD-035, Rev. 0 , Westinghouse Hanford Company.

2. Witwer, K.S., WHC-SD-WM-TRP-257, Rev 0, "Test Report for Core Drilling Ignitability Testing", 8/96.

3. Laboratory Logbook "Ignitability Testing for Core Drilling System" WHC-N-984-1, K. Witwer custodian

4. MOA 14-09-005-3666, P. D. Braun, WHC, to John Murphy, U.S. Bureau of Mines, PMM-PDB026, March 12, 1996. 


\section{DISTRIBUTION SHEET}

\begin{tabular}{|c|c|c|c|c|c|}
\hline To & \multirow{2}{*}{\multicolumn{3}{|c|}{$\begin{array}{l}\text { From } \\
\text { Engineering Testing Laboratory } \\
8 \text { A100 }\end{array}$}} & \multicolumn{2}{|l|}{ Page 1 of 1} \\
\hline Distribution & & & & \multicolumn{2}{|c|}{ Date $10 / 4 / 96$} \\
\hline \multicolumn{4}{|l|}{ Project Title/Work Order } & \multicolumn{2}{|c|}{ EDT No. 601039} \\
\hline \multicolumn{4}{|c|}{$\begin{array}{l}\text { WHC-SD-WM-TP-512, REV } 0 \\
\text { TESTING THE PROPAGATION OF FLAMMABLE GASSES IN A CORE SAMPLING } \\
\text { DRILL STRING }\end{array}$} & \multicolumn{2}{|l|}{ ECN No. $\quad N / A$} \\
\hline Name & MSIN & $\begin{array}{l}\text { Text } \\
\text { With All } \\
\text { Attach. }\end{array}$ & Text Only & $\begin{array}{l}\text { Attach./ } \\
\text { Appendix } \\
\text { Only }\end{array}$ & $\begin{array}{l}\text { EDT/ECN } \\
\text { Only }\end{array}$ \\
\hline \multicolumn{4}{|l|}{ JOHN SCHOFIELD } & & \\
\hline KEITH WITWER (2 EA) & L6-13 & $x$ & & & \\
\hline $\begin{array}{l}\text { KEN CASHDOLLAR ( } 3 \text { EA }) \\
\text { PITTSBURGH RESEARCH CENTER } \\
\text { COCHRANS MILL ROAD } \\
\text { PO BOX } 18070 \\
\text { PITTSBURGH, PA } 15236\end{array}$ & & $x$ & & & \\
\hline CENTRAL FILES & $A 3-88$ & $x$ & & & \\
\hline
\end{tabular}

